\title{
O KONSTYTUTYWNEJ WSPÓŁZALEŻNOŚCI WYJAŚNIANIA I IDENTYFIKOWANIA CZYNNOŚCI KONWENCJONALNYCH
}

\section{WPROWADZENIE I ZAGADNIENIA POJĘCIOWE}

Niniejsze opracowanie mieści się w ramach szeroko pojętej teorii czynności konwencjonalnych i dotyczy współzależności między identyfikacją a intencjonalnym wyjaśnianiem tychże czynności. Pojęcie czynności konwencjonalnej zostało wprowadzone w polskiej teorii prawa w latach siedemdziesiątych ${ }^{1}$. Trzeba zauważyć, że teoria czynności konwencjonalnych wciąż się rozwija ${ }^{2}$ i jest stosowana w szczegółowych naukach prawnych przy analizie ich problemów ${ }^{3}$. Pojęcie czynności konwencjonalnej zostało wprowadzone na potrzeby analiz teoretycznoprawnych, jednakże można powiedzieć, że ma ono bardziej ogólna doniosłość kulturową i filozoficzną. W związku z tym zakres teorii czynności konwencjonalnych jest ściśle związany, a czasami wręcz się pokrywa, z zakresem rozważań innych teorii w ramach innych dyscyplin humanistycznych. Tylko przykładowo można wskazać teorię aktów mowy ${ }^{4}$, teorię faktów instytucjonalnych ${ }^{5}$ czy też społeczno-regulacyjną teorię kultury powstałą w polskiej filozofii kultury ${ }^{6}$. Z drugiej strony zakres teorii czynności konwencjonalnych jest ściśle związany z zakresem problemów rozważanych w ramach szczegółowych nauk o prawie obowiązującym (np. teorii czynu w nauce prawa karnego czy też teorii oświadczeń woli w nauce prawa cywilnego).

Można więc powiedzieć, że istnienie czynności konwencjonalnych dostrzegane jest $\mathrm{w}$ wielu teoriach $\mathrm{z}$ zakresu filozofii i innych nauk humanistycznych oraz społecznych, jednakże różne teorie w różny sposób i za pomocą różnej terminologii konceptualizuja fakt istnienia omawianych tutaj czynności. Ze względu na wskazana, w pewnym sensie konieczna, „interdyscyplinarność" rozważań dotyczących czynności konwencjonalnych w niniejszym opracowaniu będę koncentrować się nie tyle na różnicach między odmiennymi ujęciami,

\footnotetext{
${ }^{1}$ Nowak et al. (1972): 73-99.

${ }^{2}$ W szczególności: Czepita (1996); (2016); (2017); ale również np. Patryas (2005) czy też Bator (2000); (2004).

${ }^{3}$ Zob. np. Radwański (1977), a także Janusz-Pohl (2017) (zob. omówienie literatury na s. 21 i n. tejże pracy).

${ }^{4}$ Zapoczątkowana przez prace J.L. Austina, w szczególności Austin (1962).

${ }^{5}$ W szczególności: Anscombe (1958): Searle (1995); (2002); (2010).

${ }^{6}$ W szczególności Kmita, Banaszak (1991).
} 
ile na podobieństwie polegającym na tym, że wszystkie one dostrzegają istnienie wskazanych czynności oraz reguł.

W związku z powyższym $\mathrm{w}$ pierwszej kolejności potrzebne będa pewne uwagi o charakterze pojęciowym. Przez „czynności konwencjonalne” rozumiem takie czynności, którym reguły nadają określony sens kulturowy. Reguły konstruujące czynności konwencjonalne pozwalają na redeskrypcję określonych czynów przez zakwalifikowanie ich jako przypadków dokonania określonych czynności konwencjonalnych (czyny te stanowią substrat materialny odpowiednich czynności konwencjonalnych). Na przykład reguły mowy nadają określonym słowom wypowiedzianym w określonych okolicznościach kulturowy sens czynności przeproszenia kogoś, zawarte zaś w prawie reguły nadają skinięciu głową w pewnych okolicznościach kulturowy sens czynności zawarcia umowy. Ponieważ reguły te konstytuują określone czynności konwencjonalne, w dalszej części będę (używając terminologii Searle’a) nazywał je regułami konstytutywnymi.

W dalszej kolejności należy odróżnić pytania o identyfikację od pytań o wyjaśnienie. Zadając pytanie: „co zrobił P?”, chcemy dowiedzieć się, jakiego konkretnie czynu dokonała osoba $P$. Chcemy więc zidentyfikować czyn, który został dokonany przez $P$. Pytania tego rodzaju można nazwać „pytaniami o identyfikację". Gdy z kolei zadajemy pytanie: „dlaczego $P$ zrobił $A$ ?”, to chcemy znaleźć jakieś wyjaśnienie faktu dokonania przez podmiot $P$ czynu $A$. Wyjaśnienie to może polegać na wskazaniu różnego typu faktów, jednak szczególną rolę odgrywają wyjaśnienia wskazujące na powody dokonania $P$, a wśród nich z kolei - wyjaśnienia wskazujące na intencję (zamiar) podmiotu. Takie pytania można nazwać „pytaniami o intencjonalne wyjaśnienie”. Pytania o identyfikację oraz pytania o intencjonalne wyjaśnienie mimo ich odmiennej treści są ze sobą w istotny sposób powiązane. Powiązanie to nabiera szczególnej doniosłości w przypadku czynności konwencjonalnych. W tym bowiem przypadku możemy zauważyć, że odpowiedzi na wskazane pytania sa od siebie istotnie współzależne, a szczególną odmianą tejże współzależności jest współzależność konstytutywna. Przedmiotem niniejszego opracowania będzie analiza tejże współzależności oraz zarysowanie jej związków z pewnymi podstawowymi zagadnieniami z zakresu teorii czynu oraz teorii wyjaśniania.

Niniejszy artykuł dotyczy wyjaśnień intencjonalnych, czyli takich, które odwołuja się do intencji podmiotu oraz jego wiedzy. Z tego względu należy poświęcić nieco uwagi samemu pojęciu intencji. W pierwszej kolejności trzeba zauważyć, że z filozoficznego punktu widzenia jest ono w istotnej mierze sporne. Różne prezentowane w literaturze ujęcia oferuja w pewnym stopniu odmienne odpowiedzi na pytanie, czym jest intencja. Można jednak powiedzieć, że współczesna filozoficzna refleksja na temat intencji bazuje na powszechnie przyjmowanym wyróżnieniu trzech kontekstów, w których pojawia się słowo „intencja”. Pierwszy (1) ma miejsce wtedy, gdy mówimy, że ktoś zachował się w określony sposób intencjonalnie (,intencja” jako zachowanie intencjonalne).

7 W dalszej części będę przyjmował konwencję terminologiczna, zgodnie z którą,zachowanie” może polegać na „działaniu” bądź „zaniechaniu”. 
Mówiąc w uproszczeniu, można powiedzieć, że ktoś dokonał $C$ intencjonalnie wtedy, gdy dokonał $C \mathrm{z}$ intencją dokonania $C$. Drugi kontekst (2) pojawia się wtedy, gdy chcemy powiedzieć, że ktoś zachował się w określony sposób z intencją zrealizowania w ten sposób jakiegoś dalszego czynu (dokonał $C \mathrm{z}$ intencją dokonania przez to dalszego czynu czy też wywołania skutku $S$ - ,intencja” jako cel czynu). Trzeci (3) z kolei występuje wtedy, gdy mówimy o intencjach na przyszłość ( $P$ ma zamiar dokonania $A$ w przyszłości - ,intencja” jako zamiar przyszłego zachowania; intencja na przyszłość). Filozoficzna refleksja na temat intencji zmierza do określenia wzajemnej relacji między wskazanymi „formami” intencji i odnalezienia ich wspólnej jedności.

Niniejszy artykuł nie wymaga jednak rozważania filozoficznych zagadnień związanych z intencją (np. czy jest ona odrębnym stanem mentalnym czy też nie). Wystarczy zaznaczyć, że intencja, czymkolwiek jest, zawsze dotyczy jakiegoś czynu. Jest tak nawet w przypadku intencji na przyszłość, choć w takim przypadku czyn ten jest jedynie planowanym przyszłym zachowaniem, które ktoś ma zamiar podjaćc. Dlatego też w formule „intencja $I$ ' za I podstawić można zmienną $C$ jako odnosząca się do dowolnego czynu i otrzymać formułę „intencja dokonania $C^{\circ}$. Jeżeli więc wskazanie określonej intencji I ma stanowić explanans wyjaśniania intencjonalnego, to można przyjąć, że polega on na wskazaniu intencji dokonania jakiegoś czynu $C$.

W dalszej kolejności trzeba również zauważyć, że logiczna struktura wyjaśniania intencjonalnego może być przedstawiana różnie, w zależności od przyjętego modelu wyjaśniania ${ }^{8}$. Uwagi zawarte w niniejszym opracowaniu są niezależne od przyjęcia jakiegoś konkretnego modelu, co jednak nie oznacza, że nie mogą one być one traktowane jako jeden z argumentów przy rozważaniu trafności poszczególnych modeli. Podjęcie tego zagadnienia wymaga jednak odrębnego opracowania.

\section{WSPÓŁZALEŻNOŚĆ IDENTYFIKOWANIA I WYJAŚNIANIA CZYNNOŚCI KONWENCJONALNYCH}

Analizując relację pytania o indentyfikację do pytania o wyjaśnienie, trzeba stwierdzić, że drugie jest bez watpienia zależne od pierwszego (jest pochodne w stosunku do pierwszego). Uzyskanie określonej odpowiedzi na pytanie o identyfikację stanowi presupozycję pytania o intencjonalne wyjaśnienie. Uzyskanie prawdziwej bądź fałszywej odpowiedzi na drugie z tych pytań możliwe jest jedynie po uzyskaniu odpowiedzi na pierwsze $\mathrm{z}$ nich (pytanie o intencję dokonania $C$ zakłada, że dokonanie $C$ zostało już przez nas ustalone).

W przypadku czynności konwencjonalnych wydaje się, że również pierwsze ze wskazanych pytań jest w jakiś sposób zależne od drugiego. Ogólnie

${ }^{8}$ W szczególności należy wskazać następujące modele: dedukcyjno-nomologiczny, semantyczny, wyjaśniania przez specyfikację, przyczynowo-mechaniczny. Zob. Kuipers (1985); Vanderbeeken (2004). 
rzecz ujmując, zależność owa polega na tym, że dla identyfikacji dokonania czynności konwencjonalnej $C k$ konieczne jest odwołanie się do wyjaśniania intencjonalnego, a jego wynik wpływa w pewien sposób na tę identyfikację. Odpowiedzi na wskazane pytania są wzajemnie współzależne. To jednak prima facie wywołuje podstawową metodologiczną trudność, która można wyrazić pytaniem: w jaki sposób możemy wyjaśniać coś, skoro nie wiemy, co właściwie wyjaśniamy? W związku z tym musimy bliżej przyjrzeć się różnym aspektom współzależność między pytaniami o identyfikację a pytaniami o intencjonalne wyjaśnienie.

Wydaje się, że wspomnianą współzależność można analizować w trzech różnych aspektach. Można powiedzieć, że przejawia się ona w trzech aspektach: (1) pierwotnym, (2) konstytutywnym oraz (3) epistemicznym. Aspekty te przejawiają się $\mathrm{w}$ praktyce życia codziennego, a także w innych obszarach, jak na przykład w prawie (przy ustalaniu czynu w prawie karnym, wykładni czynności prawnych w prawie cywilnym, czy też interpretacji przepisów prawnych).

Aspekt pierwotny jest związany z pojmowaniem jakiegokolwiek czynu jako świadomego zachowania kierowanego wolą (intencjonalnego) i może być wyrażony za pomoca formuły: „podmiot $P$ dokonał czynności konwencjonalnej $C k^{1}$ ”, ponieważ „podmiot $P$ kierował się intencją dokonania jakiegoś czynu $C$ ”. Innymi słowy - za czynność konwencjonalną można uznać jedynie coś, co zostało dokonane intencjonalnie (posiada jakieś wyjaśnienie intencjonalne).

Z kolei aspekt epistemiczny związany jest z dążeniem do najlepszego wyjaśnienia czynności konwencjonalnej $C k^{1}$ przez cel podmiotu i może być wyrażony za pomocą formuły: „podmiot $P$ dokonał czynności $C k^{1}$ (nie zaś $C k^{2}, \ldots$ $C k^{\mathrm{n}}$ )", ponieważ „podmiot $P$ kierował się intencja zrealizowania celu $S$, a $C k^{1}$ jest najlepszym środkiem dla zrealizowania $S^{\prime \prime}$. W tym przypadku chodzi nie tyle o intencjonalne dokonanie $C k$, ile o dokonanie $C k$ z intencja wytworzenia przez to jakiegoś innego stanu rzeczy $S$, który można rozpatrywać jako cel podmiotu. Założenie tego celu pozwala na rozpoznanie $C k^{1}$ jako tej właśnie, a nie innej czynności konwencjonalnej. W takim przypadku intencjonalne wyjaśnienie z jednej strony pozwala na ustalenie celu, z drugiej zaś - pozwala na identyfikację określonej czynności konwencjonalnej. Załóżmy na przykład, że prawodawca ustanowił przepis prawny o określonym brzmieniu. Jednak w świetle reguł języka przepis ten jest wieloznaczny i może być rozumiany na dwa sposoby (w dwóch znaczeniach) $M^{1}$ i $M^{2}$. Ustanowienie przepisu znaczącego $M^{1}$ jest więc inną czynnościa konwencjonalna niż ustanowienie przepisu znaczącego $M^{2}$. Załóżmy dalej, że ustanowienie przepisu znaczącego $M^{1}$ znajduje intencjonalne wyjaśnienie w realizacji celu prawodawcy, dla ustanowienia przepisu znaczacego $M^{2}$ nie sposób zaś znaleźć żadnego racjonalnego wyjaśnienia. Intencjonalne wyjaśnienie staje się więc w takim przypadku nie tylko instrumentem ustalenia celu prawodawcy, lecz także sposobem na rozwianie wątpliwości co do tego, jaka w istocie czynność konwencjonalna została dokonana ${ }^{9}$.

\footnotetext{
${ }^{9}$ Zob. Bogucki (2016).
} 
Zarówno aspekt podstawowy, jak i epistemiczny są istotne, jednakże szczególnie interesujące zagadnienia wiążą się z aspektem konstytutywnym, który będzie przedmiotem dalszej części rozważań.

\section{ASPEKT KONSTYTUTYWNY}

Konstytutywna współzależność między pytaniem o identyfikację a pytaniem o wyjaśnienie czynności konwencjonalnej związana jest z faktem, że określone czynności konwencjonalne są w pewien sposób współkonstytuowane przez intencję ich dokonania. Jak zauważa się w literaturze filozoficznej ${ }^{10}$, takie czynności, jak na przykład powitanie czy obietnica, nie mogą być dokonane inaczej, jak tylko intencjonalnie. Wskazane czynności sa paradygmatycznymi przykładami czynności konwencjonalnych. Wydaje się, że określona intencja jest niezbędna dla ich dokonania. Można powiedzieć, że w takim przypadku posiadanie określonej intencji wymagane jest przez jedną z odpowiednich reguł konstytutywnych kreujących daną czynność.

Aspekt konstytutywny związany jest więc z uznaniem określonej intencji jako koniecznego warunku określonej czynności konwencjonalnej. W takim przypadku współzależność między pytaniem o identyfikację a pytaniem o wyjaśnienie polega na tym, że odpowiedź na pierwsze z nich (,podmiot $P$ dokonał określonej czynności konwencjonalnej $C k^{1 ”}$ ) zakłada udzielenie określonej odpowiedzi na pytanie o wyjaśnienie (,podmiot $P$ dokonał określonej czynności konwencjonalnej $C k^{1}$, ponieważ podmiot $P$ kierował się intencją dokonania tejże czynności $C k^{1 "}$ ). Aspekt konstytutywny wydaje się charakterystyczny właśnie dla czynności konwencjonalnych, nie zaś dla czynów o charakterze czysto psychofizycznym. Trudno na przykład uznać, że identyfikacja określonego czynu jako „kopnięcia kogoś w nogę” uzależniona jest od przypisania działającemu intencji kopnięcia w nogę (działający mógł kierować się np. intencja kopnięcia piłki stojącej tuż obok bądź też jakąśs jeszcze inną intencja).

Aspekt konstytutywny jest w pewnym sensie nadbudowany nad aspektem pierwotnym. W aspekcie konstytutywnym wymaga się nie tylko dokonania czynności intencjonalnie (z jakaśs intencja), ale ponadto z określona (taka, a nie inna) intencja. Można więc powiedzieć, że aspekt konstytutywny zakłada aspekt pierwotny - wymaganie określonej intencji zakłada wymóg intencjonalności. Jeżeli więc uznamy, że z aspektem konstytutywnym mamy do czynienia w przypadku wszystkich czynności konwencjonalnych (a w takim kierunku będzie zmierzać niniejsze opracowanie), to aspekt konstytutywny niejako „konsumuje” aspekt pierwotny. Jeżeli jednak zakwestionujemy istnienie współzależności konstytutywnej bądź uznamy, że ma ona miejsce tylko w przypadku niektórych czynności konwencjonalnych, to i tak musimy uznać współzależność identyfikowania i wyjaśniania w aspekcie (na poziomie) pierwotnym.

\footnotetext{
${ }_{10}$ Anscombe (1963): 84-85.
} 
W dalszej kolejności należy zauważyć, że zjawisko konstytutywnej współzależności jest doniosłe $\mathrm{z}$ punktu widzenia zagadnień dyskutowanych $\mathrm{w}$ teorii czynu. Dwa podstawowe z nich to samo pojmowanie czynu, a także przyczynowy charakter jego intencjonalnego wyjaśniania.

\section{KONSTYTUTYWNA WSPÓŁZALEŻNOŚĆ A POJMOWANIE CZYNU}

Pojmowanie czynu uzależnione jest w istotnym stopniu od odpowiedzi na pytanie, czy można określoną intencję postrzegać jako element określonego czynu. Przecząca odpowiedź na to pytanie zakłada, że czynem jest jedynie zdarzenie opisywalne $\mathrm{w}$ oderwaniu od intencji podmiotu (takie ujęcie jest więc czysto „behawioralne” i „eksternalne”). Jeżeli jednak czynności konwencjonalne będziemy traktować jako szczególną odmianę czynów i przyznamy, że w przypadku czynności konwencjonalnych charakterystyka czynności odwołuje się do takiej, a nie innej intencji, to na wskazane pytanie należy odpowiedzieć twierdzaco. Należy dodać, że czynności konwencjonalne maja charakter „znaczący” (ich wytwory są znakami w rozumieniu semiotyki), dlatego też powyższe pytanie można sformułować odpowiednio również w stosunku do pojęcia znaku (czy znakiem $\Phi$ jest jedynie coś dokonane z intencja $\Phi$ ?). W dalszej części trzeba więc poddać bliższej analizie konsekwencje zjawiska konstytutywnej współzależności.

Ktoś mógłby zauważyć, że potraktowanie intencji jako elementu czynności konwencjonalnej zmienia sens terminów występujących w odpowiedziach na pytanie o identyfikację oraz pytanie o wyjaśnienie. Jeżeli uznamy, że „(i) podmiot $P$ dokonał określonej czynności konwencjonalnej $C k^{1}$ " tylko wtedy, gdy „(ii) $P$ dokonał określonej czynności konwencjonalnej $C k^{1}$ oraz (iii) podmiot $P$ dokonał określonej czynności konwencjonalnej $C k^{1}$, ponieważ (iv) kierował się intencją dokonania tejże czynności konwencjonalnej $C k^{1}$ ", to $C k^{1}$ nie będzie występować za każdym razem w tym samym znaczeniu. Jeżeli uznamy, że określona czynność konwencjonalna obejmuje określone zachowanie się (bądź zaniechanie) wraz z odpowiednia intencja, to $C k^{1} \mathrm{w}$ (i) oraz (iv) będzie nazwa tej czynności, z kolei w (ii) oraz (iii) będzie nazwą odpowiedniego zachowania się (działania ewentualnie zaniechania), które na mocy odpowiedniej reguły konstytutywnej rozpoznawane jest jako substrat tejże czynności konwencjonalnej (działanie bądź zaniechanie, przez które dokonuje się tej czynności). Zatem na przykład skinięcie głową jest w wielu kulturach traktowane jako substrat czynności potwierdzenia. W związku z tym można powiedzieć, że (i) podmiot $P$ dokonał czynności konwencjonalnej potwierdzenia tylko wtedy, gdy (ii) $P$ skinął głową oraz (iii) $P$ skinął głowa, ponieważ (iv) kierował się intencją dokonania czynności konwencjonalnej potwierdzenia.

W związku z powyższym można by więc powiedzieć, że w zjawisku konstytutywnej współzależności nie ma nic wyjątkowego. Związane jest ono po prostu z tym, że jakiś fakt $A$ (działanie bądź zaniechanie) oraz fakt $B$ (intencja) 
łącznie tworzą fakt $C$ (czynność konwencjonalna). Takie stanowisko pomija jednak dwie bardzo istotne (i powiązane ze soba) okoliczności: (1) fakty $A$ i $B$ maja zasadniczo inny status epistemiczny oraz (2) fakt $B$ poznajemy przez poznanie faktu $A$.

Fakt $A$ zachodzi w fizykalnej rzeczywistości i jest w zasadzie bezpośrednio obserwowalny. Fakt $B$ posiada natomiast w jakimśs sensie odmienny status. Nawet jeżeli utożsamimy intencję ze stanem mentalnym (co nie jest jedynym ujęciem występujacym $\mathrm{w}$ literaturze), a ten $\mathrm{z}$ kolei ze zdarzeniem w centralnym układzie nerwowym, to bez watpienia nie ma on charakteru bezpośrednio obserwowalnego dla osób dokonujących interpretacji określonego zachowania. Nawiązując do odróżnienia na „obserwowalne” i „teoretyczne”, można w uproszczeniu powiedzieć, że działania lub zaniechania będą miały charakter obserwowalny, intencje zaś - teoretyczny. Poznanie intencji ma miejsce przede wszystkim przez poznanie działań i zaniechań. Jest tak w szczególności w przypadku osoby interpretującej czyn innej osoby w momencie jego dokonywania. Oczywiście przy ustalaniu intencji potencjalnie istotne mogą okazać się różne inne okoliczności, sam jednak fakt takiego, a nie innego działania (czy zaniechania) ma status w jakiśs sposób uprzywilejowany. Warto nawiązać tutaj do intuicji wyrażonej przez Von Wrighta w jego teorii wyjaśniania intencjonalnego ${ }^{11}$. W tym ujęciu wyjaśnianie intencjonalne jest postrzegane jako sylogizm praktyczny, a przesłanki tego sylogizmu (odpowiednie pragnienie i przekonanie) weryfikowalne są na podstawie postulatów znaczeniowych przez sam fakt dokonania określonego czynu. O odpowiednim pragnieniu i przekonaniu można mówić tylko, gdy odpowiedni czyn został dokonany. Taki sylogizm praktyczny nie może więc pełnić funkcji predykcyjnej ${ }^{12}$.

Szczególny związek między czynem a intencją zachodzi w przypadku czynności konwencjonalnych. W takim przypadku wydaje się, że identyfikacja określonego czynu angażuje nas w szczególny sposób w twierdzenia dotyczące przekonań i intencji podmiotu. Dlatego właśnie z punktu widzenia pragmatyki języka co najmniej „dziwaczne” wydają się takie wypowiedzi, jak np. „niniejszym stwierdzam, że właśnie mi to obiecałeś, i jednocześnie stwierdzam, że nie miałeś takiego zamiaru” albo „niniejszym stwierdzam, że właśnie mnie przeprosiłeś, i jednocześnie stwierdzam, że nie wiesz o tym, że to zrobiłeś”. Wspomniana „dziwaczność” wywołana jest intuicja, zgodnie z która istnieje różnica między rzeczywistą obietnicą czy też przeprosinami a jedynie wypowiedzeniem słowa „obiecuję" czy też „przepraszam”13. Dla rzeczywistej obietnicy czy też przeprosin niezbędne wydaje się istnienie określonych przekonań i intencji. Czysto „behawioralne” pojmowanie czynności konwencjonalnej (zgodnie z którym jest nią jedynie zdarzenie opisywalne w oderwaniu od intencji podmiotu) zupełnie zaciera wskazaną różnicę.

11 Von Wright (1971).

${ }^{12}$ Kuipers (1985): 182.

${ }^{13}$ Dlatego właśnie w teorii aktów mowy wiele uwagi poświęca się warunkom trafności (felicity conditions) aktów mowy. 
Bez wątpienia to, w jaki sposób w danej kulturze pojmuje się takie czynności, które w niniejszym opracowaniu nazywane sa konwencjonalnymi, uzależnione jest $\mathrm{w}$ istotnym stopniu od całościowej wizji świata, a w szczególności przekonań na temat charakteru związku między tymi czynnościami a ich skutkami. Wyobraźmy sobie na przykład nieznane plemię, które odwiedza pewien antropolog. Podczas spotkania z wodzem antropolog ściska serdecznie jego dłoń. To jednak powoduje powszechne oburzenie i wściekłość członków plemienia, a antropolog zostaje uwięziony. Okazuje się, że w świetle reguł tej kultury wspomniany gest stanowi najgorszą możliwą obrazę. Członkowie plemienia z wielkim zrozumieniem odnieśli się do tłumaczenia antropologa, że nie mógł on nikogo obrazić, ponieważ nie miał pojęcia, że odpowiednie zachowanie uznawane jest za obraźliwe. Mimo tego jednak stwierdzili, że „w oczach bogów" obraza pozostaje obraza, a antropolog musi zostać ukarany. Można powiedzieć, że członkowie tej wyobrażonej kultury pojmowali wskazaną czynność czysto „behawioralnie” (i jednocześnie zapewne nigdy nie nazwaliby jej „konwencjonalną”). Taki sposób myślenia jest więc bliższy kulturom, które związku między omawianymi czynnościami a ich skutkami nie traktują jako konwencjonalnego, postrzegając go raczej jako niezależny od człowieka związek o charakterze magicznym czy też przyczynowo-skutkowym (na podobieństwo związku między fizykalnym zdarzeniem a jego fizykalnymi skutkami). Przynajmniej w odniesieniu do zlaicyzowanych kultur Zachodu behawioralne ujęcie czynności konwencjonalnych wydaje się więc nieadekwatne. $\mathrm{W}$ odniesieniu do nich ujęcie to nie oddaje adekwatnie związku między czynnościami konwencjonalnymi a intencjami, a ponadto w pewnym sensie podważa ich konwencjonalność.

Ujmując rzecz jeszcze inaczej, można powiedzieć, że podstawowym argumentem przemawiającym za traktowaniem odpowiednich intencji jako pojęciowo powiązanych z odpowiednimi czynnościami konwencjonalnymi jest sama idea konwencjonalności jako niczego więcej, jak tylko „skodyfikowanego” przekazywania ludzkich intencji. Jeżeli będziemy postrzegać konwencjonalność jako służebną względem przekazywania intencji, to uzasadnione wydaje się pojęciowe powiązanie intencji z czynnościami konwencjonalnymi. Jeżeli natomiast będziemy dopatrywać się odrębnego „konwencjonalnego świata” niezależnego od ludzkich intencji, to pojęciowe wiązanie intencji z czynnościami konwencjonalnymi może wydawać się nieuzasadnione.

Trzeba w tym zauważyć, że krytykowane powyżej „behawioralne” (skutkowe) pojmowanie czynności wydaje się akceptowane na gruncie dotychczasowej wersji teorii czynności konwencjonalnych ${ }^{14}$. Trudno jednak nie oprzeć się wrażeniu, że stanowisko takie nie było nigdy przedmiotem dostatecznie pogłębionych rozważań. Autorzy publikacji wprowadzającej pojęcie czynności konwencjonalnej nie zajęli w tym zakresie wyraźnego stanowiska, natomiast w znacznie późniejszej publikacji Stanisław Czepita wyraźnie stwierdził (odwołując się częściowo do ustaleń Wojciecha Patryasa), że czynności konwencjo-

${ }^{14}$ Zob. jednak Janusz-Pohl (2017), która skutkowo pojmuje substrat materialny, finalistycznie zaś czynność konwencjonalną. 
nalne należy ujmować skutkowo ${ }^{15}$. Za takim stanowiskiem przemawiać maja dwa argumenty. Po pierwsze, ustalając dokonanie czynności konwencjonalnej $C k$ nie pytamy o to, dlaczego $P$ dokonał $C k$. Chcemy wiedzieć, jakiej czynności konwencjonalnej dokonał $P^{16}$. Zgodnie z drugim argumentem finalistyczne rozumienie czynu nie pozwala na wyjaśnianie w drodze interpretacji humanistycznej i miesza rozpoznanie czynu z jego wyjaśnianiem ${ }^{17}$. Rozpoznanie czynu pojętego finalistycznie wymaga znajomości tego, co pozwala już ów czyn zinterpretować (wyjaśnić).

Oba powyższe argumenty sa nietrafne. Oczywiste jest, że czym innym jest pytanie o to, „czy $P$ pozdrowił $R$ ?”, a czym innym pytanie: „dlaczego $P$ pozdrowił $R$ ?". Z tego jednak w żaden sposób nie wynika, że nie możemy traktować odpowiedzi na pytanie: „dlaczego $P$ zdjął nakrycie głowy?” jako elementu procedury rozpoznania zdjęcia nakrycia głowy jako czynności pozdrowienia. To właśnie wyjaśnienie zdjęcia nakrycia głowy w drodze interpretacji humanistycznej pozwala na rozpoznanie go jako powitania (co wymaga oczywiście najpierw rozpoznania czynu zdjęcia nakrycia głowy). Rozpoznanie czynności konwencjonalnej pojętej finalistycznie wymaga znajomości tego, co pozwala wyjaśnić dokonanie jej substratu materialnego, nie zaś całej tej czynności (to jest już odrębny proces wyjaśniania). Oba wskazane argumenty ewidentnie mieszają czynność konwencjonalna z jej substratem.

Do podstawowych, wskazywanych już wcześniej, wątpliwości związanych ze skutkowym („behawioralnym”) pojmowaniem czynność konwencjonalnych dodać można jeszcze jedną: ujęcie takie wywołuje nieakceptowalne konsekwencje w przypadku dwóch różnych czynności konwencjonalnych, które jednak mają taki sam substrat materialny. W naszej kulturze kiwnięcie głowa „od góry do dołu” traktowane jest jako substrat czynności potwierdzenia, z kolei w kulturze bułgarskiej jest to substrat czynności zaprzeczenia. Przyjmując ujęcie skutkowe i abstrahując od intencji oraz wiedzy działajaccego, przyjać by trzeba, że ktoś kiwający głową we wskazany sposób przeczy i potwierdza jednocześnie (tylko odwołanie się do wiedzy i intencji pozwala stwierdzić, czy przeczy, czy potwierdza).

Uznanie, że elementem każdej czynności konwencjonalnej jest odpowiednia intencja (nazwijmy takie ujęcie „intencjonalnym”), również pociaga za sobą pewną negatywną i zupełnie nieintuicyjną konsekwencję. Jeżeli bowiem określona czynność konwencjonalna może być dokonana jedynie z określona intencją podmiotu (co zakłada również posiadanie określonej wiedzy), to wszyscy inni poza nim w zasadzie nigdy nie będą w stanie stwierdzić ponad wszelką wątpliwość, że wskazana czynność została dokonana. Takie ujęcie prowadzić by musiało do chaosu w sferze kultury i obrotu prawnego. W szczególności w przypadku dokonania czynności, przez którą ktoś zobowiązuje się do czegoś, skrajnie nieintuicyjne byłoby uznanie, że może on ją „unicestwič” przez wskazanie, że w istocie nie miał intencji jej dokonania.

\footnotetext{
15 Czepita (1996): 148; Patryas (1988): 14-33.

${ }_{16}$ Czepita (1996): 129.

17 Patryas (1988): 20-21; (1979): 271-283.
} 
Aby uniknąć wspomnianej trudności, należy wyraźnie oddzielić zagadnienia ontologiczne od zagadnień epistemologicznych. Czym innym jest uznanie, że określona intencja jest elementem czynności konwencjonalnej, a czym innym określenie zakresu okoliczności mogących stanowić dopuszczalny dowód czy tė̇ argument za istnieniem bądź nieistnieniem tejże intencji. Rozmaite względy etyczne lub prawne moga przemawiać za pewnymi ograniczeniami w zakresie dowodzenia. Innymi słowy, nie każda okoliczność, podniesiona przez kogokolwiek w każdym czasie i w dowolny sposób, może zostać uznana za dopuszczalny dowód nieistnienia odpowiedniej intencji, nawet jeżeli z czysto poznawczego punktu widzenia okoliczność ta jest istotna. Stopień takich „konwencjonalnych” ograniczeń zależy przede wszystkim od kulturowej wagi danej czynności oraz od tego, jak bardzo zmienia ona normatywną sytuację podmiotu lub innych osób (w szczególności ich sytuację etyczną lub prawna). Inny charakter będzie miała na przykład sytuacja polegająca na tym, że ktoś macha ręka przed taksówka, co zostaje potraktowane przez taksówkarza jako jej wezwanie, jednakże po podjechaniu auta machająca osoba twierdzi, że „tylko machała sobie ręką", nie mając intencji wezwania taksówki, a inny charakter sytuacja polegajaca na tym, że ktoś przez przyrzeczenie publiczne zaciaga prawne zobowiązanie pieniężne, a następnie twierdzi, że wcale „nie miał takiej intencji”.

Wspomniane wyżej ograniczenia określające akceptowalny sposób wykazywania braku odpowiedniej intencji można tutaj umownie nazwać regułami falsyfikacji. Ich źródłem mogą być zarówno wyraźne regulacje prawne, jak również bardziej „rozmyte” normy zakładane przez instytucjonalną praktykę w innej sferze określonej kultury (jak np. tzw. etyka aktów mowy). Oczywiście rekonstrukcja wskazanych reguł będzie w drugim przypadku bardziej problematyczna niż w pierwszym. Niezależnie od tego reguły falsyfikacji, wspólnie z regułami konstytutywnymi kreującymi daną czynność konwencjonalna oraz regułami określajaccymi jej normatywne konsekwencje, będą kształtować funkcjonowanie tejże czynności w określonej sferze danej kultury.

Dobrym przykładem reguły falsyfikacji może być na przykład specyficzna reguła przyjmowana przy wykładni oświadczeń woli w przypadku umów o świadczenie na rzecz osoby trzeciej. W nauce prawa cywilnego wskazuje się, że ustalenie rzeczywistego zamiaru podmiotu składającego oświadczenie nie jest dopuszczalne wtedy, gdy oświadczenie to jest kierowane do nieograniczonego kręgu adresatów bądź też nieokreślony z góry krąg osób może w przyszłości powołać się na jego treśćc ${ }^{18}$. W takim przypadku interpretacja polega na ustaleniu jego powszechnie przyjętego znaczenia.

Nawiązując do wcześniejszego przykładu z antropologiem i nieznaną kultura, trzeba w tym miejscu dodać, że z teoretycznego punktu widzenia reguły falsyfikacji mogą być tak restrykcyjne, że będą w ogóle wyłączać jakąkolwiek możliwość falsyfikacji twierdzenia o posiadaniu odpowiedniej intencji. Powstaje oczywiście pytanie, czy w takim przypadku nie jest to już przejaw behawioralnego pojmowania czynności konwencjonalnej. Trudno jest udzielić na

${ }_{18}$ Zob. np. Machnikowski (2004): 240. 
nie jednoznacznej odpowiedzi. Nawet jeżeli z powodów teoretycznych będziemy w takim przypadku obstawać za ujęciem intencjonalnym, to w praktyce ta czynność konwencjonalna będzie funkcjonowała tak, jakby była rozumiana behawioralnie.

Warto w tym miejscu dodać również, że traktowaniu odpowiedniej intencji jako elementu określonej czynności konwencjonalnej nie przeczy w żaden sposób fakt, iż niektóre czynności konwencjonalne przypisywane są podmiotom niebędącym osobami fizycznymi (np. prawodawcy czy spółce akcyjnej). Choć problematyka intencji podmiotów zbiorowych stanowi odrębne złożone zagadnienie, które trudno tutaj omawiać, to nie budzi wątpliwości sama możliwość przypisania intencji takim właśnie podmiotom. Istotnymi pytaniami sa oczywiście pytania o to, jak ustalać taka intencję, jakie są w tym przypadku reguły falsyfikacji, a także w jaki sposób taka intencja istnieje (np. intencja prawodawcy racjonalnego istnieje w jakiś inny sposób niż intencje osób tworzących kolegialne ciało tworzące dany akt normatywny). Niezależnie jednak od wspomnianych problemów istota zagadnienia pozostaje taka sama - aby uznać, że określony podmiot dokonał określonej czynności konwencjonalnej, musimy zaangażować się w twierdzenie dotyczące jego intencji (nie sposób np. stwierdzić, że prawodawca racjonalny ustanowił normę $N$, mimo że nie miał takiej intencji; choć można oczywiście powiedzieć, że niektórzy członkowie legislatywy takiej intencji nie mieli).

Podsumowując dotychczasowe uwagi, możemy w sposób bardziej szczegółowy przedstawić strukturę konstytutywnej współzależności między identyfikowaniem a wyjaśnianiem czynności konwencjonalnych. Przyjęliśmy, że odpowiednia intencja jest elementem określonej czynności konwencjonalnej. W związku z tym można powiedzieć, że: „podmiot $P$ dokonał określonej czynności konwencjonalnej $C k^{1}$ ” tylko wtedy, gdy „podmiot $P$ dokonał $S\left(C k^{1}\right)$ oraz podmiot $P$ dokonał $S\left(C k^{1}\right)$, ponieważ kierował się intencją dokonania określonej czynności konwencjonalnej $C k^{1}$ ”. W tej formule „S$\left(C k^{1}\right)$ ” będzie oznaczało określone działanie albo zaniechanie traktowane na mocy odpowiednich reguł konstytutywnych jako dokonanie określonej czynności (czyli substrat materialny tejże czynności). Jednak podstawowym świadectwem (dowodem) posiadania odpowiedniej intencji jest właśnie samo ,S(Ck $\left.k^{1}\right)$, ponieważ intencja ta stanowi wyjaśnienie zajścia $S\left(C k^{1}\right)$. Należy tutaj jednak uwzględnić również ewentualne inne okoliczności, które w świetle odpowiednich w danym przypadku reguł falsyfikacji mogą wskazywać, że mimo zajścia $S\left(C k^{1}\right)$ brak było intencji dokonania czynności konwencjonalnej $C k^{1}$. Jeżeli te falsyfikujace okoliczności oznaczymy jako „F(Ck1)”, to argumentacyjną strukturę identyfikowania określonej czynności konwencjonalnej $C k^{1}$ można wyrazić następująco: ,jeżeli podmiot $P$ dokonał $S\left(C k^{1}\right)$, to podmiot $P$ dokonał $S\left(C k^{1}\right)$, ponieważ kierował się intencją dokonania czynności konwencjonalnej $C k^{1}$, a więc podmiot $P$ dokonał określonej czynności konwencjonalnej $C k^{1}$, chyba że $F\left(C k^{1}\right)$ ". Trzeba dodać, że w przypadku gdy odpowiednie reguły będą tak restrykcyjne, że wyłączać będą wszelką możliwość falsyfikacji, to część po „chyba że” będzie pusta. Innymi słowy: działanie (albo zaniechanie) w sposób przewidziany przez reguły konstytutywne określonej czynności konwencjonalnej daje podstawę do 
podważalnego wyjaśnienia go przez intencję dokonania tejże czynności konwencjonalnej, co z kolei stanowi podstawę do podważalnego stwierdzenia, że czynność ta została dokonana. W skrajnych jednak przypadkach wskazana podważalność może zostać wyłączona.

\section{POJMOWANIE CZYNNOŚCI KONWENCJONALNYCH A KAUZALIZM I ANTYKAUZALIZM}

Z dotychczasowych rozważań wynikają również pewne wnioski dotyczące natury intencjonalnego wyjaśniania czynu. W ostatnich dziesięcioleciach jedno z najbardziej dyskutowanych pytań w teorii czynu dotyczyło tego, czy intencje (i ogólnie - powody zachowania) można traktować jako przyczyny zachowania, a w związku z tym, czy wyjaśnianie intencjonalne (i ogólnie wyjaśnianie odwołujące się do powodów zachowania) daje się zredukować do wyjaśniania przyczynowego. Pytania te podzieliły autorów na dwie grupy: kauzalistów (wiązanych z nazwiskiem Davidsona), którzy na wspomniane pytania udzielają odpowiedzi twierdzącej, oraz antykauzalistów (wiązanych z nazwiskiem Wittgensteina), którzy odpowiadają na nie przecząco. Debata między kauzalistami i antykauzalistami jest dość złożona, wielowątkowa i daleka od konkluzji ${ }^{19}$. Wydaje się, że sytuację w tym zakresie istotnie utrudniają dwie okoliczności. Po pierwsze, samo pojęcie przyczyny nie jest dostatecznie jasne, a w ramach tejże debaty słowo ,przyczyna” nie zawsze funkcjonuje w tym samym znaczeniu. Po drugie, nie jest jasne, co to znaczy, że jeden typ wyjaśniania redukuje się do drugiego. Analizowanie tych zagadnień znacznie wykracza poza zakres niniejszego opracowania, jednakże dotychczasowe ustalenia pozwalają na sformułowanie kilku istotnych uwag.

Po pierwsze, ponieważ określona intencja jest elementem określonej czynności konwencjonalnej, to trudno intencję tę rozpatrywać jako przyczynę tejże czynności. Jak już wskazywała Anscombe ${ }^{20}$, to, że w przypadku pewnych czynów intencja nie stanowi elementu wyraźnie wyodrębnionego w stosunku do samego czynu, stanowi jeden z argumentów przemawiających przeciwko traktowaniu intencji jako przyczyn. Takie stanowisko jest jednak przez niektórych traktowane jako nieprzekonujące. Setiya wskazuje, że nawet jeżeli intencja nie da się wyodrębnić z samego czynu, to i tak można ją pojmować jako jego przyczynę ${ }^{21}$. Jego zdaniem stanowisko odmienne zakłada nadmiernie waskie pojęcie przyczyny. Autor zauważa, że nawet jeżeli nie mogę dokonać obietnicy bez intencji jej dokonania, to mimo tego moge jej dokonać, ponieważ mam intencję jej dokonania - odpowiednia intencja może być więc rozumiana jako przyczyna zachowania. Choć taki argument prima facie wydaje się przekonujący, to jednak wywołuje on pewne istotne trudności. Ponieważ określona

\footnotetext{
19 Przegląd debaty zob. Alvarez (2007); D’Oro, Sandis (2013); Candlish, Damnjanovic (2013).

20 Anscombe (1983): 179-180.

21 Setiya (2007): 57.
} 
intencja jest elementem określonej czynności konwencjonalnej $C k^{1}$, to uznanie jej jednocześnie za przyczynę $C k^{1}$ prowadzi do przyznania, że intencja ta w pewnym zakresie jest swoją własną przyczyną. To z kolei prowadzi do nadmiernie szerokiego pojęcia przyczyny. Trzeba by bowiem przyznać, że niektóre przyczyny, takie jak intencje, mają swoistą samozwrotną naturę. Jeżeli jednak poważnie potraktujemy postulat Hume'a (zgodnie z którym, aby uznać $A$ za przyczynę $B$, zjawiska te muszą być od siebie różne), to w rozpatrywanym przypadku nie możemy mówić o przyczynach oraz wyjaśnianiu przyczynowym (chyba że przez wyjaśnianie przyczynowe będziemy rozumieć coś innego niż podawanie przyczyn ${ }^{22}$ ).

Trzeba jednak w tym miejscu zauważyć, że przy przyjęciu pewnych założeń możliwe jest kauzalne analizowanie czynności konwencjonalnych. Jak już wskazano wcześniej, w przypadku dokonania określonej czynności konwencjonalnej $C k^{1}$ mamy do czynienia nie tyle z dokonaniem $C k^{1} \mathrm{z}$ intencja dokonania $C k^{1}$, ile z dokonaniem substratu czynności konwencjonalnej $S\left(C k^{1}\right)$ wraz z intencja dokonania czynności konwencjonalnej $C k^{1}$ (np. wypowiedzeniem określonych słów wraz z intencją przeproszenia). Należy zauważyć, że dotychczasowe uwagi nie wykluczają możliwości analizowania relacji między intencją dokonania określonej czynności konwencjonalnej a działaniem (albo zaniechaniem) będącym jej substratem jako relacji kauzalnej. Można więc powiedzieć, że na przykład intencja potwierdzenia jest przyczyna, która powoduje skinięcie głową. Wydaje się jednak, że kauzalne ujęcie czynu musiałoby być połączone z uznaniem, że jedynymi „prawdziwymi” czynami są czysto psychofizyczne „poruszenia ciała”. Zgodnie z takim ujęciem czynności konwencjonalne nie byłyby czynami, tylko bardziej złożonymi faktami instytucjonalnymi „nadbudowanymi” nad czynami. Jeżeli jednak, tak jak w niniejszym artykule, przyjmuje się założenie, że czynności konwencjonalne są odmianą czynów, to trudno uznać, że kauzalizm jest stanowiskiem właściwym w odniesieniu do wszystkich czynów (a więc że w przypadku wszystkich czynów intencje ich dokonania można traktować jako ich przyczyny).

\section{PODSUMOWANIE}

Na zakończenie niniejszego opracowania należy podkreślić, że między odpowiedziami na pytania: ,jakiej czynności konwencjonalnej $C k$ dokonał podmiot $P$ ?" oraz ,jaką intencją $I$ kierował się $P$, dokonując $C k$ ?”, istnieje istotna współzależność. Współzależność ta może być rozpatrywana w aspekcie pierwotnym, epistemicznym, a przede wszystkim w aspekcie konstytutywnym.

Argumentacyjną strukturę konstytutywnej współzależności można przedstawić zgodnie z formuła: ,jeżeli podmiot $P$ dokonał substratu materialnego

22 Np. Queloz (2018): 167-169, proponuje, aby wyjaśnienia przyczynowe rozumieć szeroko: nie tylko jako wyjaśnienia podające przyczyny, ale również jako wyjaśnienia podające relewantne cechy sytuacji, która skojarzona jest z przyczyną. 
określonej czynności konwencjonalnej, to podmiot $P$ dokonał go, ponieważ kierował się intencją dokonania tej czynności konwencjonalnej, a więc podmiot $P$ dokonał owej czynności konwencjonalnej, chyba że zachodza okoliczności, które w świetle odpowiednich w danym przypadku reguł falsyfikacji wskazuja, że brak było intencji dokonania tejże czynności.

Konstytutywna współzależność między identyfikowaniem a wyjaśnianiem czynności konwencjonalnych skłania do pojmowania odpowiedniej intencji jako elementu samej czynności, co jest ujęciem odmiennym od zdającego się przeważać w teorii czynności konwencjonalnych skutkowego pojmowania czynu. Postrzeganie odpowiedniej intencji jako elementu czynności konwencjonalnej przemawia z kolei przeciwko kauzalizmowi, traktującemu intencje jako przyczyny zachowań. W związku z konstytutywną współzależnością należy również postulować istnienie (obok reguł konstytutywnych) właściwych dla odpowiedniej czynności reguł weryfikacji właściwej intencji.

Olgierd Bogucki

Uniwersytet Szczecinski

olgierd.bogucki@usz.edu.pl

https://orcid.org/0000-0002-9337-5973

Alvarez, M. (2007). The causalist/ anti-causalist debate in the theory of action: what it is and why it matters, [w:] A. Leist (ed.), Action in Context. Berlin: 103-123.

Anscombe, G.E.M. (1958). On brute facts. Analysis 18(3): 69-72.

Anscombe, G.E.M. (1963). Intention. 2nd edn. Oxford.

Anscombe, G.E.M. (1983). The causation of action, [w:] C. Ginet, S. Shoemaker (eds.), Knowledge and Mind. Oxford: 174-190.

Austin, J.L. (1962). How to Do Things with Words. J.O. Urmson (ed.), Oxford.

Bator, A. (2000). Użycie normy prawnej w regulacji stosunków gospodarczych. Wrocław.

Bator, A. (2004). Kompetencja w prawie i prawoznawstwie. Wrocław.

Bogucki, O. (2016). Model wykładni funkcjonalnej w derywacyjnej koncepcji wykładni prawa. Szczecin.

Candlish, S., Damnjanovic, N. (2013). Reasons, actions, and the will: the fall and rise of causalism, [w:] M. Beaney (ed.), The Oxford Handbook of the History of Analytic Philosophy. Oxford: 689-708.

Czepita, S. (1996). Reguły konstytutywne a zagadnienia prawoznawstwa, Szczecin.

Czepita, S. (2016). O koncepcji czynności konwencjonalnych w prawie, [w:] M. Smolak (red.), Wykładnia konstytucji. Aktualne problemy i tendencje, Warszawa: 109-147.

Czepita, S. (2017). O pojęciu czynności konwencjonalnej i jej odmianach. Ruch Prawniczy, Ekonomiczny i Socjologiczny 79(1): 85-102.

D'Oro, G., Sandis, C. (eds.) (2013). Reasons and Causes: Causalism and Non-Causalism in the Philosophy of Action. New York.

Janusz-Pohl, B. (2017). Formalizacja i konwencjonalizacja jako instrumenty analizy czynności karnoprocesowych w prawie polskim. Poznań.

Kmita, J., Banaszak G. (1991). Społeczno-regulacyjna koncepcja kultury. Warszawa.

Kuipers, T.A.F. (1985). Logic of intentional explanation. Communication and Cognition 18(1/2): 177-198.

Machnikowski, P. (2004). Komentarz do art. 65 k.c., [w:] E. Gniewek (red.), Kodeks cywilny. Komentarz. Tom 1. Warszawa: 237-245.

Nowak, L., Wronkowska S., Zieliński, M., Ziembiński, Z. (1972). Czynności konwencjonalne w prawie. Studia Prawnicze 33(2): 73-99. 
Patryas, W. (1979). Interpretacja humanistyczna a skutkowe ujęcie czynności. Poznańskie Studia z Filozofii Nauki 4: 271-283.

Patryas, W. (1988). Interpretacja karnistyczna. Studium metodologiczne. Poznań.

Patryas, W. (2005). Performatywy w prawie. Poznań.

Radwański, Z. (1977). Teoria umów. Warszawa.

Searle, J. (1995). The Construction of Social Reality. New York.

Searle, J. (2002). How to derive "ought" from "is", [w:] Ph. Foot Theories of Ethics. Oxford: 101114.

Searle, J. (2010). Making the Social World: The Structure of Human Civilization. Oxford.

Setiya, K. (2007). Reasons without Rationalism. Princeton.

Vanderbeeken, R. (2004). Models of intentional explanation. Philosophical Explorations 7(3): 233-246.

Von Wright, G.H. (1971). Explanation and Understanding. London.

Queloz, M. (2018). Davidsonian causalism and Wittgensteinian anti-causalism: a rapprochement. Ergo 5(6): 153-72.

Quine, W.V., Ullian, J.S. (1970). The Web of Belief. New York.

\section{ON THE CONSTITUTIVE CORRELATION BETWEEN THE IDENTIFICATION AND INTENTIONAL EXPLANATION OF CONVENTIONAL ACTS}

\section{Summary}

The article examines the specific correlation (interdependence) between the identification and intentional explanation of conventional acts (in particular, legally significant conventional acts). The author describes this interdependence as 'constitutive' because in this case intentional explanation plays a constitutive role for the identification of a conventional act. This can be expressed through the formula: 'person $\mathrm{P}$ performed conventional act $\mathrm{CA}^{1}$ ' only if 'person $\mathrm{P}$ performed conventional act $\mathrm{CA}^{1}$ because person $\mathrm{P}$ was driven by the intention to perform conventional act $\mathrm{CA}^{1}$.' The article analyses the logical and argumentative structure of the abovementioned correlation. On the basis of the analysis, the author claims that a constitutive correlation indicates that a relevant intention should be perceived as an element of the act itself (in contrast to the view adopted in the theory of conventional acts) and that verification rules relevant for the given act exist alongside the constitutive rules. Recognizing the relevant intention as an element of the conventional act stands in opposition to causalism, which treats intentions as the causes of actions.

Keywords: theory of law; intentional explanation; conventional acts; concept of an act; causalism; anti-causalism 
